\title{
Editorial
}

\section{Ciclo de Avanços em Clínica Psiquiátrica: a realidade da integração científica e associativa}

Temos a satisfação de entregar aos nossos leitores este suplemento especial da Revista de Psiquiatria do RS com os relatórios a serem debatidos no XVI Ciclo de Avanços em Clínica Psiquiatra.

A publicação prévia dos relatórios dos grupos de estudo é um objetivo desde há muito desejado e que se repete nessa nova edição do Ciclo. Sentimo-nos gratificados, pois, como popularmente se diz, o hábito faz o monge. Assim, ao conseguirmos entregar antecipadamente os relatórios do ciclo de avanços desse ano, estamos contribuindo para que essa publicação torne-se um hábito de divulgação de nossa produção científica.

Os benefícios são muitos. A publicação dos relatórios registra de forma perene o trabalho de nossos psiquiatras, amplia a divulgação de seu conteúdo para além do tempo e do espaço restrito do ciclo de avanços e deixa, de forma indelével, a marca da qualidade de nossas reflexões atuais e desempenho profissional. Também permite que os participantes do ciclo de avanços recebam textos que passam pelo padrão de qualidade da Revista de Psiquiatria do Rio Grande do Sul; dessa forma, a qualidade de impressão, a diagramação e a padronização textual formam um conjunto mais harmônico e agradável ao leitor. Daí depreende-se a impor- tância desta publicação.

Para que esta publicação se tornasse possível, o trabalho começou cedo, em meados do ano passado, quando os organizadores do XVI Ciclo Dra. Berenice Gomes Giannetti e Drs. Gabriel Chittó Gauer e Matias Strassburger prontamente se engajaram no ideal dessa publicação e estimularam a adesão dos coordenadores dos grupos temáticos e de seus componentes.

Os relatórios são frutos do trabalho de muitos psiquiatras que, desde meados de 2002 , vêm se reunindo sistematicamente para nos oferecer o resultado de seus encontros e, desse modo, disponibilizar os debates que, em 12 de abril próximo, far-se-ão no Novotel, em Porto Alegre.

Os relatórios também expressam a integração de conhecimentos que desde há muito é estimulada pela Sociedade de Psiquiatria do Rio Grande do Sul, entidade que congrega os psiquiatras gaúchos e que busca, não apenas acolher as variadas correntes científicas da psiquiatria na atualidade em nosso meio, mas ir além, promovendo a divulgação e o debate sério entre seus afiliados.

Temas complexos e abertos a maior entendimento como violência doméstica, psicodinâmica do adolescente envolvido com drogas, pro- 
grama de assistência ao portador de transtornos limítrofes, vivências traumáticas, bases neurobiológicas e funções da consciência, ansiedades relacionadas ao estresse, os paradigmas atuais para a compreensão do gênero e desenvolvimento sexual, estão presentes para o debate. Áreas um pouco mais conhecidas, porém com constante necessidade de atualização pelos avanços contemporâneos, como os transtornos de humor, a doença de Alzheimer, farmacologia do transtorno do humor, funcionamento de uma unidade de internação psiquiátrica em hospital geral e o uso de interpretação transferencial e extratransferencial em psicoterapia, atualizam e reforçam o conhecimento, criando situações únicas para o debate e crescimento profissional de todos.

É assim que o ciclo de avanços tem acontecido nessas dezesseis edições, com riqueza de conhecimentos, divulgação de novidades e o compartir das incertezas, num espírito de busca constante pelo saber e integração científica e pessoal, de modo a propiciar, a todos, profissional e associativamente, mais satisfação.

Esse espírito é propiciado desde a diretoria da Sociedade, através de seu Presidente, Dr. Jair Rodrigues Escobar e dos demais membros da diretoria, que em muito são responsáveis pelo incentivo oferecido aos participantes do ciclo de avanços e pela liberdade e companheirismo com os quais integram os colegas e fornece o clima emocional e material para que a tarefa seja realizada.

Parabenizamos aos participantes dos grupos e à sua comissão coordenadora por mais essa conquista. O ciclo está aí, pronto para ser saboreado. E convidamos a todos para participar.

É com satisfação que nos dirigimos a todos nossos leitores através de mais uma edição para também anunciar que distribuiremos a revista por um ano para todo Brasil a partir do próximo número. Encaminhe seu artigo para ser avaliado pelo nosso conselho editorial.

Boa Leitura e até breve.

César Luís de Souza Brito e Jacó Zaslavsky

Editores 